\title{
TREATMENT OF HEAVY METALS FROM WATER BY ELECTRO-PHYTOREMEDIATION TECHNIQUE
}

\author{
Harikumar Puthenveedu Sadasivan Pillai ${ }^{1^{*}}$, Megha Tharayil' \\ 1 Water Quality Division, Centre for Water Resources Development and Management, Kozhikode - 673571, \\ Kerala, India \\ *1Corresponding author's e-mail: hps@cwrdm.org
}

Received: 2017.06.09

Accepted: 2017.08.01

Published: 2017.09.01

\begin{abstract}
The performance of electrically stimulated phytoremediation in the removal of lead, cadmium and copper was assessed in this study. A combination of phyto and electro remediation was attempted in this study for the remediation of the metals from water. Three tanks were set up with different operating conditions for this experiment: control A (only phytoremediation system), control B (only electro remediation) and treatment (combination of phyto and electro remediation). The electrically enhanced phytoremediation system and electro remediation system were operated $2 \mathrm{~h} /$ day at voltages of $4 \mathrm{~V}$ for 25 days continuously. In this experiment, the Eichhornia crassipes, an able phyto-remediator exhibited efficient and fast removal of heavy metals from synthetic solution in electro assisted phytoremediation system. The electrically enhanced phytoremediation using aluminum sheet electrodes showed better and effective removal of $\mathrm{Cd}, \mathrm{Pb}$ and $\mathrm{Cu}$ than aluminum rod electrodes. A more favorable and moderate increase of $\mathrm{pH}$ was noticed in electrically stimulated phytoremediation system. Eichhornia crassipes has a tremendous potential to reduce the maximum amount of cadmium (within 15 days), lead (within 15 days) and copper (within 10 days) under electrically stimulated condition. Under electrified condition, maximum amount of $\mathrm{Cd}$ and $\mathrm{Cu}$ was accumulated in the aerial parts of Eichhornia crassipes but maximum concentration of $\mathrm{Pb}$ was attained by roots. This indicates the high heavy metal accumulation capacity of Eichhornia crassipes under electrified conditions. The results showed that $4 \mathrm{~V}$ voltage is probably suitable to stimulate the Eichhornia crassipes to synthesize more chlorophyll and voltage can improve the growth and ability to resist adverse circumstances by promoting chlorophyll synthesis. Eichhornia crassipes stimulated by an electric field has grown better and assimilated more metal. Bioconcentration factor (BCF) an index of hyperaccumulation, indicates that electrically stimulated Eichhornia crassipes is a good hyper accumulator of $\mathrm{Cd}(\mathrm{BCF}=1118.18)$ and $\mathrm{Cu}(\mathrm{BCF}=1152.47)$ and a moderate accumulator of $\mathrm{Pb}(\mathrm{BCF}=932.26)$. Translocation ability (TA) ratio indicates that Eichhornia crassipes have the ability to translocate more amounts of $\mathrm{Pb}, \mathrm{Cd}$ and $\mathrm{Cu}$ to its upper portion under electrified condition. The results imply that the electro-phytoremediation technique seems to be promising in the treatment of wastewater contaminated with heavy metals.
\end{abstract}

Keywords: phytoremediation, Eichhornia crassipes, bioconcentration factor, translocation ability

\section{INTRODUCTION}

Rising levels of heavy metals in the environment, their entry into food chain and their overall consequences are of great concern to sci- entific community in the field of environmental science. The remediation of toxic heavy metals from wastewaters is recognized as one of the most important fields of water treatments, since the extreme industrial activities creates many 
dangerous pollution issues to the environment [Li et al. 2009]. Cadmium and lead are commonly encountered hazardous heavy metals and are in the EPA's list of priority pollutants [Baziar et al. 2013]. The UNEP considers lead and cadmium as the non-essential element for human life but they can compete with the essential trace elements either for the transport systems or in binding to various biomolecules. Both can accumulate in bone and may serve as a source of exposure later in life. Cadmium is a carcinogen by inhalation and is mainly affects kidneys and the skeleton. Lead is a multi-organ system toxicant and is noxious at very low exposure levels. The duration, level and timing of exposure are the factors which depends the type and severity of effects. Tri-alkyl-lead and tetra-alkyl-lead compounds are the organo-lead compounds which are more toxic than inorganic forms of lead [UNEP, 2010].

Extensive researches have been progressing for the removal of heavy metals by various methods such as ion exchange, filtration, reverse osmosis, biosorption, chemical precipitation, electrochemical treatment, solvent extraction, sedimentation, membrane separation, sensors etc. Many existing treatment techniques are not designed to address today's concerns because of its incomplete metal uptake at low level and expensive operational costs [Shah et al. 2012]. For the better availability of good water quality at a lesser cost, it is obligatory to develop some sustainable alternative treatment methods, which are more natural, novel and cost effective. Phytoremediation utilizes the advantages of the unique, selective and naturally occurring uptake capabilities of plant root systems, together with the translocation, bioaccumulation and pollutant storage/degradation abilities of the entire plant body. Also, being aesthetically pleasing, phytoremediation is on average tenfold cheaper than other remediation methods like physical, chemical or thermal. It can also be performed in situ, is solar driven and can required minimal maintenance once established [Hooda, 2007]. Phytoremediation has also been known as green remediation, botano-remediation, agro remediation and vegetative remediation [Andrew, 2007]. Phytoremediation is a plant assisted bioremediation technique, utilized to treat contaminated water and soil, including the processes like phytoextraction, phytodegradation, phytovolatilization, phytostabilization, rhizodegradation, phy- toreducation, phytostimulation, phytooxidation and phytotransformation [Ullah et al. 2014].

Utilization of AMATS (aquatic macrophytes treatment systems) for the phytoremediation of heavy metals and other pollutants is a well-established and cost effective environmental protective technique [Mahmood et al. 2005]. Copper can become extremely toxic due to leaf chlorosis, suppressed root growth and inhibit photosynthesis and reproduction of plants, when present in excessive amount, even though it is an essential micronutrient for plant metabolism. Lead diminishes chlorophyll production and cadmium toxicity also lead to some extremely sever effects on plants [Swain et al. 2014; Hammad, 2011 and Ashraf et al. 2011]. Heavy metals can create stressful conditions to the plants and their growth becomes limited or impossible and this can influence the phytoremediation. So, in our study we tried to enhance the phytoremediation capacity of Eichhornia crassipes to treat heavy metals by using electric current. The purpose of this study was to investigate the removal of lead, cadmium and copper in simulated wastewater by a phytoremediation system coupled with electric field.

\section{MATERIALS AND METHODS}

\section{Preparation of synthetic heavy metals solution}

The simulated wastewater was made by dissolving $\mathrm{Pb}\left(\mathrm{NO}_{3}\right)_{2}, \mathrm{CuSO}_{4} \cdot 5 \mathrm{H}_{2} \mathrm{O}$, and $\left(3 \mathrm{CdSO}_{4}\right) \cdot 8 \mathrm{H}_{2} \mathrm{O}$ in tap water. All chemicals used were of the highest purity available and of analytical grade procured from Merck. The initial heavy metal concentrations of the simulated wastewater were determined by Atomic Absorption Spectrophotometer.

\section{Collection of plant for this study}

A fast-growing perennial aquatic plant and prolific free-floating aquatic weed, Eichhornia crassipes (Water hyacinth) was used for the treatment of heavy metals in this experiment. Young plants of Eichhornia crassipes were collected from Kottooli wetland in Kozhikode City. Eichhornia crassipes can easily adapt to several aquatic conditions and perform an important role in extracting and accumulating many metals from water. Hence, it is utilized as an ideal 
candidate for the phytoremediation of toxic trace elements from variety of water bodies [Weiliao and Chang, 2004]. Collected plants were put in a hydroponic system containing tap water, for acclimatization period, before being exposed to heavy metal contaminants.

\section{Experimental design and sampling strategy}

Three tanks $(45 \times 30 \times 15 \mathrm{~cm})$ were setup with different operating conditions.

Tank 1: Control A (with plant and without electric current)

Tank 2: Control B (without plant and with electric current)

Tank 3: Treatment (with plant and with electric current)

Twelve liters of synthetic heavy metal solution was taken in each tank. An electric power supply (DC) was used for providing constant voltage between working electrodes (i.e. in control B and treatment). Initially, aluminum rods $(0.10 \mathrm{~m}$ height, $0.019 \mathrm{~m}$ breadth and $2.04 \mathrm{~mm}$ thickness) and sheets $(0.15 \mathrm{~m}$ height, $0.10 \mathrm{~m}$ breadth and $0.2 \mathrm{~mm}$ thickness) were used as electrodes and both indoor and outdoor experiments were also conducted. Based on the results and condition of the plant, outdoor experiment using aluminum sheets as electrodes were preferred for further study. To remove the oxide and passivation layer from aluminum surface, the electrodes were rubbed with sandpaper and energized by dipping them in $5 \mathrm{~N} \mathrm{HCl}$ for 1 minute. The electrodes in the tanks were positioned vertically. Plants were placed very close to the electrodes. $0.01 \mathrm{M} \mathrm{KCl}$ was used as supporting electrolyte. Circulation of water was maintained using a submersible pump. The experimental setup is depicted in Figure 1. Different voltages: $2 \mathrm{~V}, 3 \mathrm{~V}, 4 \mathrm{~V}$ and $5 \mathrm{~V}$ were operated $2 \mathrm{~h} /$ day for 10 days. Due to the formation of bubbles and heat generation, phytoremediation system operated at a voltage of $5 \mathrm{~V}$ was stopped after 2 days. From the results obtained, 4V was selected as an optimum voltage for further experiment. The experiment was operated $2 \mathrm{~h} /$ day at voltages of $4 \mathrm{~V}$ for 25 days continuously. All the units were operated outdoors. Water samples were taken in every 5 days at about 10:30 A.M. On every sampling day, $\mathrm{pH}, \mathrm{EC}$, TDS and temperature were measured by using PCS Testr35 instrument. When the experiment was finished, plants from two units (control A and treatment) were sampled and dried in a hot air oven. The residual $\mathrm{Pb}, \mathrm{Cd}$ and $\mathrm{Cu}$ concentrations in water were determined by Atomic Absorption Spectroscopy AAS (Thermo Series) with GF 95.

\section{ANALYTICAL PROCEDURES}

$20 \mathrm{~mL}$ of water samples were taken from each tank in every 5 days at around 10:30 A.M. Plant samples were collected at the end of the experiment and rinsed using tap water twice and deionized water thrice. The Eichhornia crassipes samples were divided into leaves, stems and roots. Plant samples were oven-dried for $48 \mathrm{~h}$ at $70^{\circ} \mathrm{C}$. The oven-dried sample was ground to pass through a 100-mesh sieve and homogenized plant tissues were digested with $\mathrm{HNO}_{3}-\mathrm{HClO}_{4}$ (4:1) mixture and filtered. For quantification of heavy metals, the water samples and digested plant samples were analyzed with Atomic Absorption Spectrophotometer (Thermo Series) with GF 95. Chlorophyll (chl.a + chl.b, CHLab) was determined by optical density values $(663 \mathrm{~nm}$ and 645 $\mathrm{nm}$ using UV-Visible spectrophotometer, Thermo Evolution 201) of extracting solution, which was made by adding $80 \%$ acetone into grinding solution of $0.5 \mathrm{~g}$ of fresh leaves [Song et al. 2011].

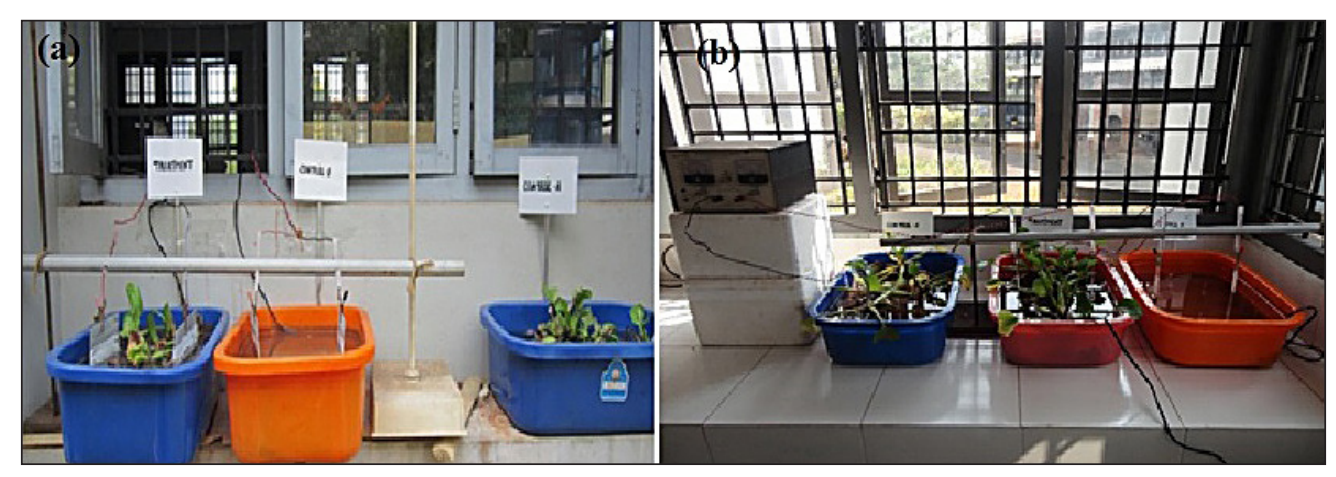

Figure 1. Experimental setup: (a) outdoor experiment and (b) indoor experiment 


\section{DATA ANALYSIS}

The bioconcentration factor (BCF) and translocation ability (TA) are the factors used to evaluate the mobility of the heavy metals from the polluted substrate into the roots of the plants and their ability to translocate the metals from roots to the harvestable aerial part. The translocation ability indicates the efficiency of the plant in translocating the accumulated metal from its roots to the upper part of the plant. Translocation ability (TA) was calculated by dividing the concentration of a trace element accumulated in the root tissues by that accumulated in shoot/leaf tissues [Liao and Chang, 2004]. TA is given by,

$$
\mathrm{TA}=\left(\mathrm{A}_{\mathrm{r}} / \mathrm{A}_{\mathrm{s}}\right)(1)
$$

where TA is the translocation ability and is dimensionless. A represents the amount of trace element accumulated in the roots ( $\mathrm{mg} \mathrm{kg}^{-1}$ dry wt), and $\mathrm{A}_{\mathrm{s}}$ represents the amount of trace element accumulated in the shoot/leaf ( $\mathrm{mg} \mathrm{kg}^{-1}$ dry wt). A larger TA ratio implies poor translocation capability. The bioconcentration factor (BCF) was calculated as the ratio of the trace element concentration in the plant tissues to the concentration of the element in the external environment [Liao and Chang, 2004]. BCF is given by,

$$
\mathrm{BCF}=(\mathrm{P} / \mathrm{E})(2)
$$

where $\mathrm{BCF}$ denotes the bioconcentration factor and is dimensionless. $\mathrm{P}$ represents the trace element concentration in plant tissues $\left(\mathrm{mg} \mathrm{kg}^{-1}\right.$ dry $\mathrm{wt})$; E represents the trace element concentration in the water $(\mathrm{mg} / \mathrm{L})$ or in the sediment $\left(\mathrm{mg} \mathrm{kg}^{-1}\right.$ dry wt). A larger ratio implies better phytoaccumulation capability. All the tests were conducted in triplicates and the data were statistically analyzed.

\section{RESULTS AND DISCUSSION}

\section{Removal of lead, cadmium and copper from synthetic solution using electro- phytoremediation system}

The initial values of the $\mathrm{pH}, \mathrm{EC}$ and TDS of the synthetic solution were found to be 6.29 $\pm 0.01,274 \pm 1.2 \mu \mathrm{S} / \mathrm{cm}$ and $193 \pm 0.78 \mathrm{mg} / \mathrm{L}$ respectively. The initial heavy metal concentra- tions of simulated water are summarized in Table 1. The metals like $\mathrm{Fe}^{2+}, \mathrm{Mn}^{2+}, \mathrm{Ni}^{2+}$ and $\mathrm{Zn}^{2+}$ were found to be within the permissible limit.

Four different voltages $2 \mathrm{~V}, 3 \mathrm{~V}, 4 \mathrm{~V}$ and $5 \mathrm{~V}$ were applied for $2 \mathrm{~h}$ /day for 10 days. We did not continue the experiment in which $5 \mathrm{~V}$ was applied due to the formation of bubbles and heat generation. Maximum removal of $\mathrm{Cd}, \mathrm{Pb}$ and $\mathrm{Cu}$ was observed in phytoremediation system operated at $4 \mathrm{~V}$ for 10 days. So $4 \mathrm{~V}$ was applied for further experiments. The plants used in outdoor experiment had grown better than the plants in indoor experiment due to the presence of sunlight. So after one week, the indoor experiment was discontinued. Treatment of lead, cadmium and copper from synthetic solution using electrically enhanced phytoremediation system was conducted using $\mathrm{Al}$ rod and $\mathrm{Al}$ sheet as electrodes and the results were compared.

\section{Variation of $\mathrm{pH}$}

$\mathrm{pH}$ changes were recorded during every 5 days and the variations were depicted in Figure 2. No significant change in $\mathrm{pH}$ was observed in control A (phytoremediation system) during study. In both experimental sets (i.e., in experiments using $\mathrm{Al}$ rod and $\mathrm{Al}$ sheet as electrodes), control A presented a lower $\mathrm{pH}$ than control B (electro-remediation system) and treatment (electrically stimulated phytoremediation). With electrical exposure, an increase in $\mathrm{pH}$ was observed in control $\mathrm{B}$ and treatment. The $\mathrm{OH}^{-}$concentration in solution increases while electrolysis is taking place, which resulted in an increase in $\mathrm{pH}$ [Song et al. 2011].

\section{Removal performance of heavy metal by electrically stimulated phytoremediation system}

The residual concentrations of $\mathrm{Cd}, \mathrm{Pb}$ and $\mathrm{Cu}$ in water collected from control A, control B and treatment are summarized in Table 2. In the experiment, where aluminum sheets were used as electrodes, the electro assisted phytoremediation system (i.e. treatment) reduced $100 \%$ of cadmium within 15 days, while in control A and control B, $48.21 \pm 1.8$ and $84.24 \pm 1.7 \%$ of cadmium reduc-

Table 1. Initial concentration of heavy metals in synthetic solution

\begin{tabular}{|c|c|c|c|c|c|c|c|}
\hline $\begin{array}{c}\text { Heavy } \\
\text { metal }\end{array}$ & $\mathrm{Cd}$ & $\mathrm{Pb}$ & $\mathrm{Cu}$ & $\mathrm{Fe}$ & $\mathrm{Mn}$ & $\mathrm{Ni}$ & $\mathrm{Zn}$ \\
\hline$(\mathrm{mg} / \mathrm{L})$ & $18.86 \pm 0.4$ & $20.34 \pm 0.23$ & $19.77 \pm 0.54$ & $0.26 \pm 0.05$ & $0.02 \pm 0.003$ & $0.04 \pm 0.001$ & $0.16 \pm 0.021$ \\
\hline
\end{tabular}


(a)

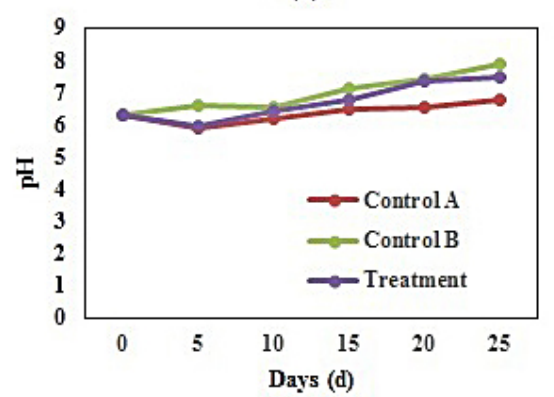

(b)

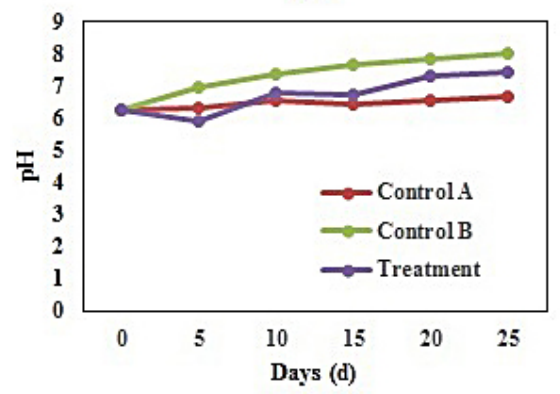

Figure 2. Variation of $\mathrm{pH}$ during the study (a) Aluminum rods as electrodes (b) Aluminum sheets as electrodes

tion was observed after 25 days of experiment. Maximum Cd was removed within a short period in electro assisted phytoremediation system. The order of removal efficiency of $\mathrm{Cd}$ is Treatment $>$ Control B > Control A. Maximum removal of lead was attained by electrically stimulated phytoremediation system within 15 days. After 25 days, it was observed that $66.67 \pm 1.2$ and 81.51 $\pm 0.7 \%$ of lead was removed in control $\mathrm{A}$ and control B respectively. The result indicated that, electrically coupled phytoremediation system exhibited better efficiency than phytoremediation system and electrolysis system in lead removal. The electrically stimulated phytoremediation system attained $100 \%$ of copper removal within 10 days and took only 5 days to attain a reduction of $99.94 \pm 0.004 \%$. The results indicated that, in control A and control B, removal of copper was found to be $89.93 \pm 1.6 \%$ and $99.98 \pm 0.003 \%$ respectively after 25 days. This result also showed that electrically stimulated Eichhornia crassipes can exhibit maximum removal efficiency for copper from water.

In the experiment where aluminum rod was used as electrode, maximum concentration of lead was removed in electro assisted phytoremediation system compared to control A and control B within 20 days. $96.96 \pm 0.22 \%$ of cadmium and $99.97 \pm 0.01 \%$ copper was eliminated by electro assisted phytoremediation system from water within 15 days. The electro assisted phytoremediation experiment where aluminum sheet was used as electrodes exhibited fast and better removal efficiency compared to the elec-

Table 2. The residual $\mathrm{Cd}, \mathrm{Pb}$ and $\mathrm{Cu}$ concentrations in water

\begin{tabular}{|c|c|c|c|c|c|c|c|}
\hline \multirow{3}{*}{ Metal } & \multirow{3}{*}{ Days } & \multicolumn{6}{|c|}{ Concentration of metals, $\mathrm{mg} / \mathrm{L}$} \\
\hline & & \multicolumn{3}{|c|}{ Aluminum sheet used as electrodes } & \multicolumn{3}{|c|}{ Aluminum rod used as electrodes } \\
\hline & & Control A & Control B & Treatment & Control A & Control B & Treatment \\
\hline \multirow{6}{*}{$\mathrm{Cd}$} & 0 & $18.86 \pm 0.4$ & $18.86 \pm 0.4$ & $18.86 \pm 0.4$ & $20.41 \pm 0.45$ & $20.41 \pm 0.45$ & $20.41 \pm 0.45$ \\
\hline & 5 & $14.57 \pm 0.1$ & $11.23 \pm 0.21$ & $2.31 \pm 0.12$ & $15.34 \pm 0.67$ & $14.56 \pm 0.21$ & $6.22 \pm 0.42$ \\
\hline & 10 & $12.56 \pm 0.3$ & $8.74 \pm 0.15$ & $0.56 \pm 0.14$ & $13.42 \pm 0.39$ & $11.87 \pm 0.71$ & $2.54 \pm 0.34$ \\
\hline & 15 & $11.98 \pm 0.45$ & $6.41 \pm 0.34$ & $N^{*}$ & $12.17 \pm 0.47$ & $9.13 \pm 0.18$ & $0.62 \pm 0.05$ \\
\hline & 20 & $10.21 \pm 0.23$ & $5.32 \pm 0.24$ & ND* & $11 \pm 0.19$ & $7.20 \pm 0.24$ & ND* \\
\hline & 25 & $9.77 \pm 0.34$ & $2.97 \pm 0.33$ & ND* & $9.36 \pm 1.01$ & $4.72 \pm 0.37$ & ND* \\
\hline \multirow{6}{*}{$\mathrm{Pb}$} & 0 & $20.34 \pm 0.23$ & $20.34 \pm 0.23$ & $20.34 \pm 0.23$ & $19.18 \pm 0.56$ & $19.18 \pm 0.56$ & $19.18 \pm 0.56$ \\
\hline & 5 & $15.54 \pm 0.43$ & $14.98 \pm 0.28$ & $7.45 \pm 0.23$ & $14.99 \pm 0.29$ & $14.35 \pm 0.64$ & $13.11 \pm 0.74$ \\
\hline & 10 & $13.99 \pm 0.25$ & $11.97 \pm 0.13$ & $0.99 \pm 0.12$ & $13.69 \pm 0.54$ & $12.97 \pm 0.64$ & $9.35 \pm 0.36$ \\
\hline & 15 & $12.98 \pm 0.41$ & $9.87 \pm 0.17$ & ND* & $11.52 \pm 0.24$ & $8.68 \pm 0.35$ & $3.14 \pm 0.37$ \\
\hline & 20 & $8.01 \pm 0.23$ & $6.23 \pm 0.53$ & $N^{*}$ & $9.55 \pm 0.06$ & $7.35 \pm 0.25$ & $\mathrm{ND}^{*}$ \\
\hline & 25 & $6.78 \pm 0.25$ & $3.76 \pm 0.14$ & ND* & $8.18 \pm 0.30$ & $4.39 \pm 0.28$ & $\mathrm{ND}^{*}$ \\
\hline \multirow{6}{*}{$\mathrm{Cu}$} & 0 & $19.77 \pm 0.54$ & $19.77 \pm 0.54$ & $19.77 \pm 0.54$ & $19.34 \pm 0.42$ & $19.34 \pm 0.42$ & $19.34 \pm 0.42$ \\
\hline & 5 & $11.06 \pm 0.24$ & $7.03 \pm 0.31$ & $0.01 \pm 0.001$ & $12.35 \pm 0.81$ & $11.25 \pm 0.21$ & $4.93 \pm 0.24$ \\
\hline & 10 & $8.05 \pm 0.32$ & $2.01 \pm 0.12$ & $\mathrm{ND}^{*}$ & $10.27 \pm 0.38$ & $9.08 \pm 0.29$ & $0.64 \pm 0.34$ \\
\hline & 15 & $5.03 \pm 0.45$ & $1.62 \pm 0.23$ & $\mathrm{ND}^{*}$ & $7.27 \pm 0.62$ & $5.60 \pm 0.28$ & $0.01 \pm 0.002$ \\
\hline & 20 & $2.90 \pm 0.27$ & $0.09 \pm 0.09$ & $N^{*}$ & $4.92 \pm 0.38$ & $3.52 \pm 0.41$ & $\mathrm{ND}^{*}$ \\
\hline & 25 & $1.99 \pm 0.31$ & $0.004 \pm 0.001$ & $\mathrm{ND}^{*}$ & $2.94 \pm 0.20$ & $1.78 \pm 0.24$ & $\mathrm{ND}^{*}$ \\
\hline
\end{tabular}

* Not detected 
tro assisted phytoremediation system where aluminum rods were used as electrodes. In the case of cadmium, within 10 days, $97.05 \pm 0.7 \%$ was reduced in electro assisted phytoremediation experiment where aluminum sheets were used as electrodes while only $87.56 \pm 1.66 \%$ reduction was noticed in aluminum rod used in the experiment. Within 10 days, $95.13 \pm 0.6 \%$ of lead was eliminated from water in the experiment where aluminum sheets were used, while Al rod removed only $51.25 \pm 1.86 \%$ of lead. $99.94 \pm 0.004 \%$ of copper was reduced by electro assisted phytoremediation experiment where aluminum sheet used as electrodes within 5 days but only a $74.49 \pm 1.25 \%$ of reduction in copper was observed in aluminum rod used in the experiment. In control B also i.e., the system where only electrolysis is taking place, maximum removal of heavy metals was noticed when aluminum sheets were used as electrodes. The results indicate that the treatment of $\mathrm{Cd}, \mathrm{Pb}$ and $\mathrm{Cu}$ using electrically enhanced phytoremediation using aluminum sheet electrodes is more effective than aluminum rod electrode. The treatment system (electrically enhanced phytoremediation using aluminum sheet electrodes) had more favorable conditions to accumulate heavy metals than did the control A (phytoremediation system), such as the higher $\mathrm{pH}$, and the presence of aluminum ions, which caused chemical precipitation, physical adsorption and flocculation of metal. So, we had carried our further study using electrically enhanced phytoremediation using aluminum sheet electrodes.

\section{Accumulation of cadmium, lead and copper in Eichhornia crassipes}

For the detailed study, heavy metal accumulation in plants collected from control A and electrically enhanced phytoremediation system using aluminum sheet electrodes was analyzed. The segmentation of Eichhornia crassipes into root, stem and leaves was carried out. The accumulation of $\mathrm{Cd}, \mathrm{Pb}$ and $\mathrm{Cu}$ in plant parts is shown in Figure. 3. The results indicated that maximum concentration of $\mathrm{Cd}, \mathrm{Pb}$ and $\mathrm{Cu}$ were accumulated in Eichhornia crassipes collected from treatment (electrically enhanced phytoremediation) than in control A (phytoremediation). Cadmium is a toxic non-essential heavy metal and it can cause inhibitory effects on plant growth. Lu et al. 2004 reported that $\mathrm{Cd}$ can suppress the development of new roots and reduce the relative growth rates and substantially reduce the growth of Eichhornia crassipes. The control plant accumulated maximum level of $\mathrm{Cd}$ in its root but in treatment plant maximum accumulation was observed in leaf. This result indicates that Eichhornia crassipes can translocate maximum Cd to plants' aerial parts under electrified condition. Maximum concentration of $\mathrm{Pb}$ was attained by roots in both control A ( $5653.51 \mathrm{mg} / \mathrm{Kg})$ and treatment $(7532.4$ $\mathrm{mg} / \mathrm{Kg}$ ) plant. Under electrified condition, more $\mathrm{Pb}$ content was translocated to its aerial part by the treatment plant compared to control A.

Copper $(\mathrm{Cu})$ is one of the micronutrient, essential for plants at very low concentrations. However, excessive concentrations of this metal

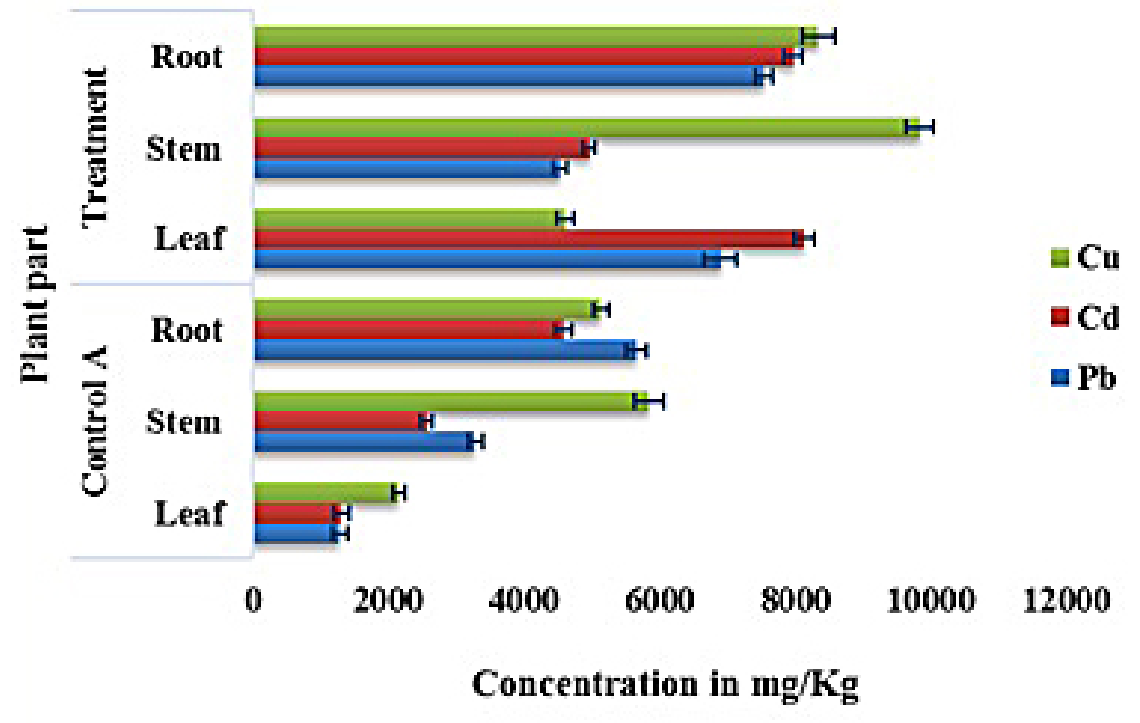

Figure 3. Accumulation of $\mathrm{Cd}, \mathrm{Pb}$ and $\mathrm{Cu}$ in plant 
are highly toxic. In both treatment $(9842.76 \mathrm{mg} /$ $\mathrm{Kg})$ and control A (5845.68 mg/Kg), the highest value of $\mathrm{Cu}$ concentration was recorded in stem. Compared to control A, treatment plant accumulated more amount of $\mathrm{Cu}$ in its aerial part under electrified condition. Many studies revealed that Eichhornia crassipes accumulated more amount of heavy metals like $\mathrm{Cd}, \mathrm{Co}, \mathrm{Cr}, \mathrm{Cu}, \mathrm{Mn}, \mathrm{Ni}, \mathrm{Pb}$ and $\mathrm{Zn}$ in its roots than in the aerial parts [Soltan and Rashed, 2003]. But our results indicated that, metals like $\mathrm{Pb}, \mathrm{Cd}$ and $\mathrm{Cu}$ are translocated to its areal parts under electrified condition. Many researchers reported the mechanisms of heavy metal removal in aquatic plants and mentioned that the main way of heavy metal uptake in emergent and surface-floating plants like Eichhornia crassipes was through the roots system. The heavy metal uptake in plants takes place by exchange of cations which occurred in the cell wall. The plants take up metals by absorption and translocation. The accumulation of heavy metals by plant tissue is by absorption to anionic sites in the cell walls. This is the reason why wetland plants can accumulate high magnitude of heavy metals in their pant parts compared to their surrounding environment [Lu et al. 2004].

\section{Bioconcentration factor and translocation ability of electrically stimulated Eichhornia crassipes}

The potential of plants for accumulating heavy metals was assessed by bioconcentration factor (BCF). The ratio between metal concentration in plant and that of the growth media expresses the bioconcentration factor (BCF), which indicates the affinity of aquatic macrophytes to a specific heavy metal or pollutant [Kabeer et al. 2014]. Bioconcentration factors of plant for $\mathrm{Cd}, \mathrm{Pb}$ and $\mathrm{Cu}$ in the present study are graphically depicted in Figure 4. Higher BCF values reflect the higher phytoaccumulation ca- pacity. Accumulation of metals by macrophytes can be affected by metal concentrations in water and the ambient metal concentration in water was the major factor influencing metal uptake efficiency. When metal concentration in water increases, the amount of metal accumulation in plants increases, but the BCF values decrease. The maximum $\mathrm{BCF}$ value for $\mathrm{Cd}$ under electrified condition was 1118.18, indicating that electrically stimulated Eichhornia crassipes is good hyper accumulator of $\mathrm{Cd}$.

If the $\mathrm{BCF}$ value is more than or equal to 1000 then that plant species is considered as a hyper accumulator. The plant having the abilities to grow in very high concentration of metal and concentrating high heavy metals in their tissues are known as hyperaccumulators [Wahab et al. 2014]. The BCFs of control $\mathrm{A}$ for $\mathrm{Pb}, \mathrm{Cd}$ and $\mathrm{Cu}$ were 502.65, 448.12 and 664.90 respectively. The BCFs for all the three metals were lower than 1,000 for control plant, i.e. plant grown under normal condition. The highest level of BCFs observed for $\mathrm{Pb}$ and $\mathrm{Cu}$ was 932.26 and 1152.47 respectively for treatment. In this study, with the BCF values of treatment plant was a little under 1000 for lead $(\mathrm{BCF}=932.26)$, this suggests that electrically stimulated plant can be considered as a moderate accumulator for $\mathrm{Pb}$. For copper this value exceeds 1000 , so electrically stimulated Eichhornia crassipes is considered as a good hyper accumulator. From Figure 3, Pb accumulated by treatment plants were largely retained in roots. This indicates that Eichhornia crassipes used in the electrically stimulated phytoremediation system bioconcentrated more amounts of $\mathrm{Pb}$ in its roots than the aerial parts. Accumulation pattern of $\mathrm{Cd}$ can be elaborated as follows:

\section{Control A: Root system >Stem system > Leaf system}

Treatment: Leaf system $>$ Root system $>$ Stem system

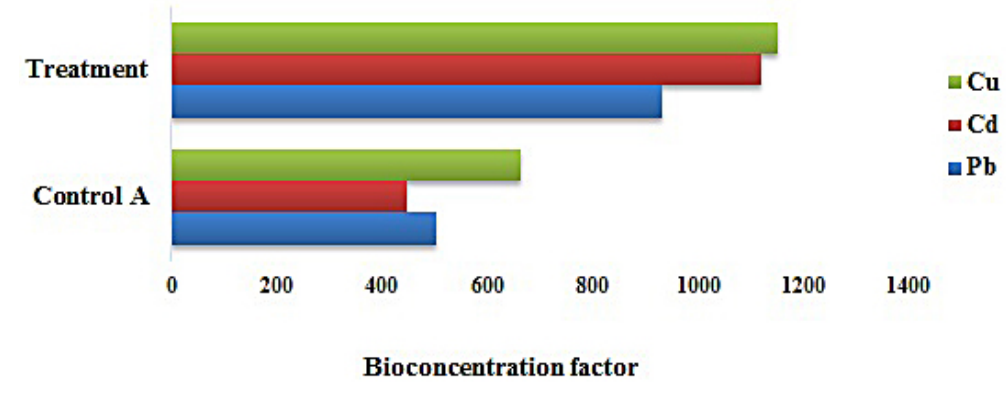

Figure 4. Bioaccumulation factors $(\mathrm{BCF})$ of $\mathrm{Pb}, \mathrm{Cd}$ and $\mathrm{Cu}$ in Eichhornia crassipes 
This result indicates that under electrified condition, leaf can effectively bioconcentrate more amount of $\mathrm{Cd}$ than roots. Copper, a component of an electron carrier called plastocyanin is active during photosynthesis. It is also a constituent of ascorbic acid oxidase, tyrosinase, and phenoloxidase [Yapoga et al. 2013]. For both phytoremediation system and electrically stimulated phytoremediation system, maximum copper was bioconcentrated in stems of Eichhornia crassipes. Under electrified condition, more amount of copper accumulation was observed. Accumulation pattern of $\mathrm{Cu}$ can be observed as follows:

\section{Control A: Stem system $>$ Root system $>$ Leaf system}

Treatment: Stem system $>$ Root system $>$ Leaf system

The root pressure and leaf transpiration are the two processes mainly controlling the translocation of metals from root to shoot/leaf. Some metals are accumulated in roots, probably due to some physiological barriers against metal transport to the aerial parts, while others are easily transported in plants. Translocation of trace elements from roots to shoots could be a limiting factor for the bioconcentration of elements in shoots [Lasat, 2000 and Lu et al. 2004]. The translocation ability (TA) is the ratio between the concentrations of a trace element accumulated in the root tissues by that accumulated in stem/leaf tissues; a larger ratio implies poorer translocation capability [Hammad, 2011]. For all the three metals, low value of TA was found in treatment system, i.e., in electrically stimulated phytoremediation system (Table 3 ). This result indicates Eichhornia crassipes have the ability to translocate more amounts of $\mathrm{Pb}, \mathrm{Cd}$ and $\mathrm{Cu}$ under electrified condition. Copper reported minimum value for translocation ability $(\mathrm{TA}(\mathrm{r} / \mathrm{s})=0.85)$ compared to other metals. This shows that Eichhornia crassipes had translocated more amount of $\mathrm{Cu}$ from root to stem under electrified condition.

\section{Variation in the production of chlorophyll}

The first and most obvious reactions of plants under heavy metal stress are often growth changes [Lu et al. 2004]. Chlorophyll content is often measured in plants in order to assess the impact of environmental stress, as changes in pigment content are linked to visual symptoms of plant illness and photosynthetic productivity. Decrease in chlorophyll in several plant species under the impact of heavy metals have reported by many researchers [Zengin and Munzuroglu, 2005]. In this study, we emphasized exploring, whether or not an electrical exposure can stimulate Eichhornia crassipes growth. In green plants' life activity, chlorophyll plays the role of absorbing, transferring and transforming energy. Leaves were collected from the control plant, treatment plant and plant from fresh water and the chlorophyll content in leaves of Eichhornia crassipes was determined using UV-Visible spectrophotometer [Song et al. 2011].

Chlorophyll content in Eichhornia crassipes leaves decreased at the beginning in all the three the plant. From the $10^{\text {th }}$ day of the study, the chlorophyll content of plant in electrically stimulated phytoremediation system was found to be gradually increasing with electrical exposure (Figure 5). The result shows an increase in the production chlorophyll with electrical stimulation. When the heavy metal exposure time increases, the production of chlorophyll content in control A decreased. Heavy metals hinder metabolic processes by inhibiting the action of enzymes, and this may be the main cause of inhibition. Heavy metal stress can cause inhibition of the enzymes responsible for chlorophyll biosynthesis which associated with decreased chlorophyll content. Cadmium was reported to affect chlorophyll biosynthesis and inhibit protochlorophyll reductase and aminolevulinic acid (ALA) synthesis [Zengin and Munzuroglu, 2005]. Cadmium strongly binds proteins, thereby decreasing the accumulation of pigment-lipoprotein complexes, including photosystem I (PSI) and PSII [Kupper et al. 2007]. The Cd induced inhibition of chlorophyll synthesis and interference with photosystems causes chlorosis of leaves of

Table 3. Translocation Ability of Eichhornia crassipes

\begin{tabular}{|c|c|c|c|c|}
\hline \multirow{2}{*}{ Metals } & \multicolumn{2}{|c|}{ Control A } & \multicolumn{2}{c|}{ Treatment } \\
\cline { 2 - 5 } & $\mathrm{TA}(\mathrm{r} / \mathrm{s})$ & $\mathrm{TA}(\mathrm{r} / \mathrm{l})$ & 1.66 & 1.09 \\
\hline $\mathrm{Pb}$ & 1.72 & 4.40 & 1.61 & 0.98 \\
\hline $\mathrm{Cd}$ & 1.79 & 3.52 & 0.85 & 1.81 \\
\hline $\mathrm{Cu}$ & 0.88 & 2.38 & $\mathrm{r} / \mathrm{s})$ \\
\hline
\end{tabular}




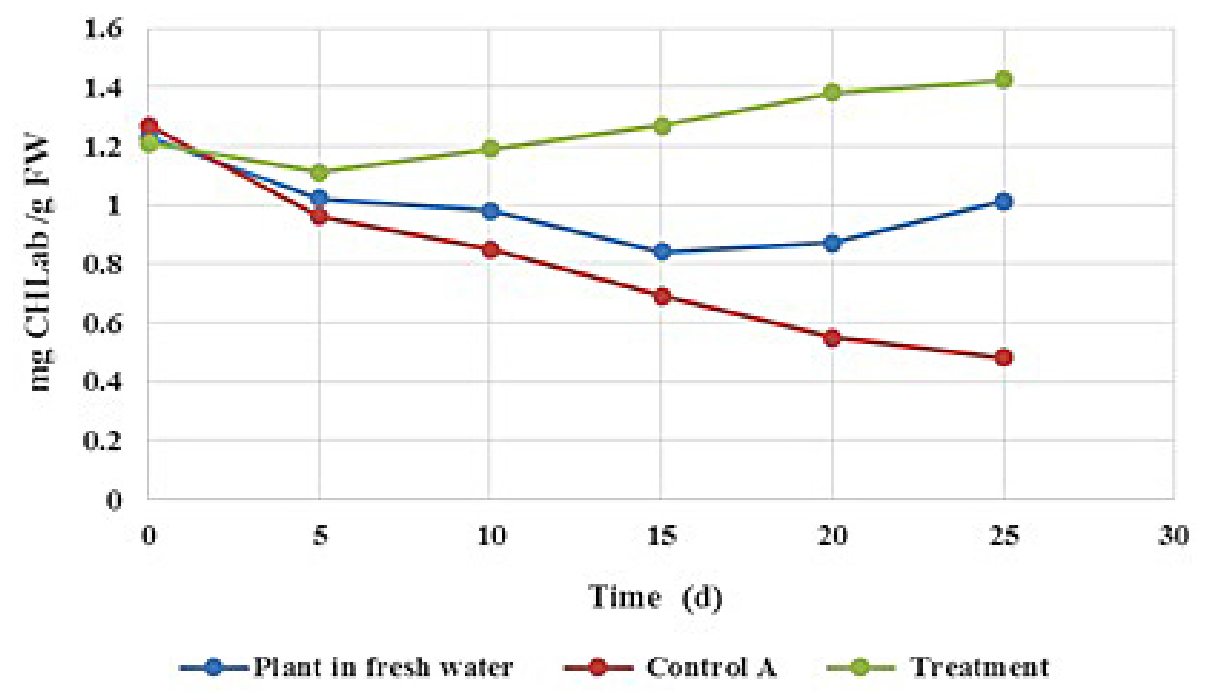

Figure 5. Variation in the production of chlorophyll

E. crassipes. Cd also reduces the contents of large and small subunits of ribulose-1, 5-bisphosphate carboxylase/oxygenase (RuBisCO) along with other enzymes of photosynthesis and chlorophyll biosynthesis. Wilting, which followed chlorosis was reported in the presence of high dose of $\mathrm{Cd}$ by researchers [Das et al. 2016]. This reduction in chlorophyll of $E$. crassipes in control A under heavy metal stress can be regarded as a specific response of the plants to metal stress, which resulted in chlorophyll degradation and inhibition of photosynthesis. The chlorophyll content might be reduced due to increased cell or tissue damage or lipid peroxidation [Das et al. 2016].

From the experimental results, it can be postulated that $4 \mathrm{~V}$ voltage is probably suitable to stimulate the Eichhornia crassipes to synthesize more chlorophyll. The longer the unit was electrified, the more obvious the stimulating effect was observed. It was in accordance with Knorr's report [Knorr, 2003]. The voltage can stimulate the plants to increase the palisade cells, chloroplast grana and thylakoid lamellas, which enhance the synthesis of chlorophyll. Eichhornia crassipes was stimulated by electric field to grow better so it can assimilate more metal.

\section{CONCLUSION}

The main goal of the present study was the assessment of the performance of electrically stimulated phytoremediation in the removal of heavy metal. Treatment of lead, cadmium and copper from synthetic solution using phytoremediation system coupled with electric field was conducted. In that experiment, the Eichhornia crassipes, an efficient phyto-remediator exhibited efficient and fast removal of heavy metals in electro assisted phytoremediation system. Both aluminum rods and sheets were used as electrodes and both indoor and outdoor experiments were also conducted. Based on the results and plants condition, outdoor experiment using aluminum sheets as electrodes was preferred for further study. The results indicate that the treatment of $\mathrm{Cd}, \mathrm{Pb}$ and $\mathrm{Cu}$ using electrically enhanced phytoremediation using aluminum sheet electrodes is more effective than aluminum rod electrode. When the electrical exposure time increases, the $\mathrm{pH}$ of the synthetic solution increased in electrolysis system, but a more favorable, moderate increase was shown by the electrically stimulated phytoremediation system. From the results, it can be postulated that $4 \mathrm{~V}$ voltage is probably suitable to stimulate the Eichhornia crassipes to synthesize more chlorophyll. Eichhornia crassipes stimulated by an electric field grown better and assimilated more metal. Heavy metal accumulation in plants collected from control A and electrically enhanced phytoremediation system using aluminum sheet electrodes indicates that maximum amount of $\mathrm{Cd}, \mathrm{Pb}$ and $\mathrm{Cu}$ were accumulated in Eichhornia crassipes collected from treatment. Eichhornia crassipes translocated maximum $\mathrm{Cd}$ and $\mathrm{Cu}$ to plants' aerial parts under electrified condition but more amount of $\mathrm{Pb}$ was bioconcentrated in roots. Electrically stimulated plant translocated more amount of $\mathrm{Pb}$ content to its aerial part compared to plant in control A. The BCFs of control A for $\mathrm{Pb}, \mathrm{Cd}$ and $\mathrm{Cu}$ were 502.65, 448.12 and 664.90 respectively. BCF an index of hyperaccumulation, indicates that electrically stimulated Eichhornia crassipes is a good hyper 
accumulator of $\mathrm{Cd}(\mathrm{BCF}=1118.18)$ and $\mathrm{Cu}(\mathrm{BCF}$ $=1152.47)$ and a moderate accumulator of $\mathrm{Pb}$ $(\mathrm{BCF}=932.26)$. Translocation ability $(\mathrm{TA})$ ratio indicates that Eichhornia crassipes have the ability to translocate more amounts of $\mathrm{Pb}, \mathrm{Cd}$ and $\mathrm{Cu}$ to its upper portion under electrified condition. Taking into account the overall results, we can state that the electro-phytoremediation technique seems to be promising in the treatment of heavy metals contaminated wastewater.

\section{REFERENCES}

1. Andrew E.A. 2007. Phytoremediation: an environmentally sound technology for pollution prevention, control and remediation in developing countries. Educational Research and Review, 2 (7), 151-156.

2. Ashraf M.A., Maah M.J. and Yusoff I. 2011. Heavy metals accumulation in plants growing in ex tin mining catchment. Int. J. Environ. Sci. Technol., 8(2), 401-416.

3. Baziar M., Mehrasebi M.R., Assadi A., Fazil M.M., Maroosi M. and Rahimi F. 2013. Efficiency of non-ionic surfactants - EDTA for treating TPH and heavy metals from contaminated soil. J Environ Health Sci Eng., 11,41.

4. Das S., Goswami S. and Talukdar A.D. 2016. Physiological responses of water hyacinth, Eichhornia crassipes (Mart.) Solms, to cadmium and its phytoremediation potential. Turk J Biol., 40, 84-94.

5. Hammad D.M. 2011. Cu, Ni and Zn Phytoremediation and Translocation by Water Hyacinth Plant at Different Aquatic Environments. Aust. J. Basic \& Appl. Sci., 5(11), 11-22.

6. Hooda V. 2007. Phytoremediation of toxic metals from soil and waste water. J. Env. Bio., 28(2), 367-376.

7. Kabeer R., Varghese R., Kochu J.K., George J., Sasi P.C. and Poulose S.V. 2014. Removal of Copper by Eichhornia crassipes and the Characterization of Associated Bacteria of the Rhizosphere System. EnvironmentAsia, 7(2), 19-29.

8. Knorr D. 2003. Impact of non-thermal processing on plant metabolite. J. Food Eng., 56 (2-3), 131-134.

9. Kupper H., Parameswaran A., Leitenmaier B., Trtilek M. and Setlik I. 2007. Cadmium induced inhibition of photosynthesis and long-term acclimation of cadmium stress in the hyperaccumulator Thlapsicaerulescens. New Phytol., 175, 655-674.

10. Lasat M.M. 2000. Phytoextraction of metals from contaminated soil: a review of plant/soil/metal interaction and assessment of pertinent agronomic issues. J. Hazard Sub. Res., 2(5), 1-25.

11. Li S., Liu W., Gu S., Cheng X., Xu Z. and Zhang Q. 2009. Spatio-temporal dynamics of nutrients in the upper Han River basin, China. J. Hazard. Mater., $162,1340-1346$.

12. Liao S.W. and Chang W.L. 2004. Heavy Metal Phytoremediation by Water Hyacinth at Constructed Wetlands in Taiwan. J. Aquat. Plant Manage, 42, 60-68.

13. Lu X., Kruatrachue M., Pokethitiyookb P. and Homyokb K. 2004. Removal of Cadmium and Zinc by Water Hyacinth, Eichhornia crassipes. Scienceasia, 30, 93-103.

14. Mahmood Q., Zheng P., Islam E., Hayat Y., Hassan M.J., Jilani G. and Jin R.C. 2005. Lab scale studies on Water hyacinth (Eichhornia crassipes marts solms) for biotreatment of textile wastewater. Caspian J. Env. Sci. 3(2): 83-88.

15. Shah B., Mistry C. and Shah A. 2012. Seizure modeling of $\mathrm{Pb}(\mathrm{II})$ and $\mathrm{Cd}(\mathrm{II})$ from aqueous solution by chemically modified sugarcane bagasse fly ash: isotherms, kinetics, and column study. Environ. Sci. Pollut. Res., 20(4), 2193-2209.

16. Soltan M.E. and Rashed M.N. 2003. Laboratory study on the survival of water hyacinth under several conditions of heavy metal concentrations. Adv Environ Res., 7, 321-34.

17. Song X., Yan D., Liu Z., Chen Y., Lu S. and Wang D. 2011. Performance of laboratory-scale constructed wetlands coupled with micro-electric field for heavy metal-contaminating wastewater treatment. Ecol. Eng., 37, 2061-2065.

18. Swain G., Adhikari S. and Mohanty P. 2014. Phytoremediation of Copper and Cadmium from Water Using Water Hyacinth, Eichhornia crassipes. International Journal of Agricultural Science and Technology, 2 (1), 1-7.

19. Ullah A., Mushtaq H., Ali H., Munis M.F.H., Javed M.T. and Chaudhary H.J. 2014. Diazotrophs-assisted phytoremediation of heavy metals: a novel approach. Environ. Sci. Pollut. Res., 22, 2505-2514.

20. UNEP. 2010. Final review of scientific information on lead, United Nations Environment Programme, Chemicals Branch, DTIE.

21. Wahab A.S.A., Ismail S.N.S., Praveena S.M. and Awang S. 2014. Heavy metals uptake of Water mimosa (Neptuniaoleracea ) and its safety for human consumption. Iranian J. Publ. Health, 43(3), 103-111.

22. Weiliao S. and Chang W.L. 2004. Heavy metal phytoremediation by water hyacinth at constructed wetlands in Taiwan. J. Aquat. Plant Manage, 42, 60-68.

23. Yapoga S., Ossey Y.B. and Kouame V. 2003. Phytoremediation of zinc, cadmium, copper and chrome from industrial wastewater by Eichhornia crassipes. Int. J. Conserv. Sci., 4(1), 81-86.

24.Zengin F.K. and Munzuroglu O. 2005. Effects of some heavy metals on content of chlorophyll, proline and some antioxidant chemicals in bean (Phaseolus vulgaris L.) Seedlings. Acta. Boil. Cracoviensia Ser. Bot., 47(2), 157-164. 